\title{
Application of nano-chitosan NPK fertilizer on growth and productivity of potato plant
}

\author{
Marwa T. Elshamy ${ }^{1}$, ELKhallal S.M ${ }^{1}$, Sherif Moussa Husseiny ${ }^{1}$ and Khaled Yehia \\ Farroh'. \\ 'Botany Department, Faculty of Women for Arts, Science and Education, Ain-Shams University, Cairo, Egypt . \\ `Nanotechnology and Advanced Material Central Lab (NAMCL), Agricultural Research Center, Giza, Egypt.
}

\begin{abstract}
Nanofertilizers improved technology for controlling release and target delivery of agrochemicals to achieve greater improvement in plant crop with lower environmental impacts. The effect of foliar application of chitosan (CS) nanoparticles loaded with nitrogen, phosphorus and potassium (NPK) on growth and yield parameters, chemical constituents and nutrients content of potato plants (spunta) grown in sandy loam soil were studied. It was applied to leaf surfaces, avoiding direct interaction with soil systems. The uptake and translocation of nanoparticles inside potato plants was investigated by transmission electron microscopy. The results revealed that nanoparticles were taken up and transported through phloem tissues. The obtained results could be summarized as follows: Foliar application with Nano CS-NPK levels (Nano 10, 50 and 100\%) significantly increased all the growth and yield parameters, photosynthetic pigments, chemical constituents of potato tuber at harvest, and macronutrients in potato leaves and tubers as compared with the control treatment. The highest effective treatment in this respect was $10 \%$ Nano CS-NPK as compered with the other two levels. Thus, accelerating plant growth and productivity by application of nanofertilizers can open new perspectives in agricultural practice.
\end{abstract}

Key words: Nanofertilizers; CS-PMAA; Chitosan polymethacrylic acid; NPK: Nitrogen (N), Phosphorus (P) and Potassium (K); Transmission electron microscopy.

\section{Introduction}

Potato (Solanum tuberosum L.) is one of the major crops in the world, after rice, wheat and maize. Potato plant belongs to Solanaceae family It is planted in 160 countries and regions worldwide (Silver, 2013). In Egypt, total production of potato 5,029,022 tons on area harvested of 184,592 ha (FAO, 2017). Potato tubers are a good source of starch, protein rich in amino acids several vitamins, and minerals (Zaheer and Akhtar, 2016).

- Corresponding author: marwa.elshamy@women.asu.edu.eg 
The biggest goal of modern agriculture is effective management of production and protection of food crop with good quality and in sufficient quantity to meet the rise in world population for an additional 2.3 billon people by 2050 worldwide (Silver, 2013). Agriculture production is severely affected by many pests and diseases that can cause considerable losses. During the past 100 years, pesticides and chemical fertilizers were used to overcome these problems and increased yield. The huge utilization of these products raised productivity, but it also led to problem for human (Adisa et al., 2019).

In recent years, Nanotechnology has important application in plant science and agriculture. Nanotechnology refers to science of manipulating and control of matter at the nanoscale at range 1-100 nm, where a unique phenomenon enables novel applications (Bhushan, 2017). Nanotechnology-derived devices are employed as delivery systems to combat crop pathogens, to minimize nutrient losses during fertilization, and to improve yield. The encapsulation of different chemicals in slow release particles can be very important for sustainable agriculture and food safety (Adisa et al., 2019). Recently, chitosan-based materials have been used to produce nanoparticles able to efficiently supply plants with chemicals and nutrients (Malerba and Cerana, 2016). Chitosan is a natural cationic polysaccharide containing D-glucosamine and N-acetyl-D-glucosamine obtained by deacetylation of chitin. In fact, chitosan has a wide range of applications due to its non-toxic, biocompatible, biodegradable, exhibits diverse biological activities and chemical stability (Malerba and Cerana, 2016).

Many applications have been reported for chitosan nanoparticles (CNM) due to a positive surface charge increases affinity towards biological membranes, resulting in enhanced reactivity with biological systems (Malerba and Cerana, 2016). Several studies were tried to use chitosan nanoparticles as a controlled release agent for nitrogen, phosphorus, and potassium fertilizers and evaluate the effect of application on wheat plants (Abdel-Aziz et al., 2016), French bean plant (Hasaneen and Abdel-aziz, 2016a) and red bean (Biosci et al., 2014). A study conducted by Chemistry (2017) evaluated the potential use of $\mathrm{Cu}$-Chitosan nanoparticle to enhance seedling growth in maize. These studies open new dimensions for chitosan nanoparticles to be used in various application of agriculture. Therefore, the aim of this study was to evaluate the effect of foliar application of Nano-chitosan in NPK fertilizer to improve growth and productivity of potato plants. 


\section{Materials and Methods}

\subsection{Preparation of nano-chitosan NPK fertilizers}

The chitosan (CS) nanoparticles were prepared by polymerization of methacrylic acid (MAA) in two step process according to (De Moura et al., 2008; Corradini, et al., 2010). The incorporation of NPK fertilizers in CS nanoparticles was obtained by dissolving suitable amounts of NPK in the following concentrations: 400 ppm, $60 \mathrm{ppm}$ and $400 \mathrm{ppm}$ respectively ( $100 \%$ concentration stands for $400 \mathrm{ppm}$ of $\mathrm{N}, 60 \mathrm{ppm}$ of $\mathrm{P}$ and $400 \mathrm{ppm}$ of $\mathrm{K}$ and other concentrations were made from these stock solutions).

\subsection{Plant material and growth conditions}

A field experiment was conducted in Botany Department, Faculty of Women's for Arts, Science and Education, Ain Shams University Cairo, Egypt. Potato tuber seeds (spunta) were supplied by Egyptian potato rot Project, Agriculture Research Center, Ministry of Agriculture, Giza, Egypt. The experiment was laid out on pots $(50 \mathrm{~cm}$ in diameter and $70 \mathrm{~cm}$ in depth) were filled with $150 \mathrm{Kg}$ soil. The physical and chemical properties of soil are measured before planting (Table 2.1) according to (Page et al., 1982).

Table 2.1 Physical and chemical properties of soil

\begin{tabular}{|c|c|c|c|c|c|c|c|c|c|c|}
\hline \multicolumn{4}{|c|}{ Soil texture } & \multirow[t]{2}{*}{ pH } & \multirow[t]{2}{*}{$\begin{array}{l}\text { E.C } \\
\left(\mathrm{dSm}^{-1}\right)\end{array}$} & \multirow[t]{2}{*}{$\begin{array}{l}\text { O.M } \\
(\%)\end{array}$} & \multirow[t]{2}{*}{$\begin{array}{l}\mathrm{CaCO}_{3} \\
(\%)\end{array}$} & \multicolumn{3}{|c|}{$\begin{array}{l}\text { Available nutrients } \\
\left(\mathrm{mg} \mathrm{Kg}^{-1}\right)\end{array}$} \\
\hline Sand $(\%)$ & Silt(\%) & Clay $(\%)$ & Texture & & & & & $\mathrm{N}$ & $\mathrm{P}$ & $\mathrm{K}$ \\
\hline 62 & 16 & 22 & Sandy loam & 6.60 & 0.27 & 0.8 & 1.1 & 44 & 3.83 & 73 \\
\hline
\end{tabular}

E.C: Electrical conduce, O.M: Organic matter.

The experiment included 35 pots and was divided in to five groups (7 pots/groups). Four tubers of equal size and weight of potatoes were planted in each pot. This was done on 24 January 2018. The groups were treated as follows:

The first group was sprayed with distilled water and represent as control.

The second group was sprayed with bulk NPK material (Biestersol 19-19-19) fertilizer.

The third, fourth and fifth group was sprayed at concentration 10, 50 and 100\% of Nano CS-NPK fertilizer.

\subsection{Data collection}

Samples collected in each treatment, representing vegetative and yield stage (after 70 and 90 days respectively from emergency) were used for determination of growth parameters and physiological analysis. 


\subsection{Measurement of growth parameters and tuber yield}

Vegetative growth as shoot and root length, fresh and dry weight, water content and dry mater percentage were determined after 70 days. While at harvest, number of tubers /plants, tuber yield /plant (g), average tuber wt. (g) and dry weight of tubes /plant (g) were measured.

\subsection{Transmission electron microscope (TEM) analysis determination}

Intracellular penetration of nanoparticles in potato plants was observed using TEM. After 10 days from applying CS-NPK Nano- fertilizer to verify the presence of Nano CS-NPK fertilizer inside potato plants. Small parts $\left(\sim 1 \mathrm{~mm}^{2}\right)$ of freshly harvested leaves were fixated in $2.5 \%(\mathrm{v} / \mathrm{v})$ glutaraldehyde at $4^{\circ} \mathrm{C}$ for $24 \mathrm{~h}$. Following fixation, the specimens were embedded in gelatin capsules. Ultra-thin sections were cut on Reichert ultra-microtome and then stained by $2 \%$ uranyl acetate (Juniper et al., 1970). Stained ultra-thin sections washed by steam distilled water and then were transferred to drops of lead citrate which were placed on a wax plate in a Petri dish for 10-20min and then were examined with TEM (Philips CM200, Mahwah, NJ, USA) at $80 \mathrm{KV}$ (Williams and Carter, 1996).

\subsection{Estimation of photosynthetic pigment}

Extraction of photosynthetic pigment according to (Arnon, 1949). Concentrations of pigments were determined using equations published by (Lichtenthaler and Buschmann, 2001):

$$
\begin{aligned}
& \text { Chlorophyll } a\left(\mu \mathrm{g} \mathrm{ml}^{-1}\right)=12.25 A_{663.2}-2.79 A_{646.8} \\
& \text { Chlorophyll } b\left(\mu \mathrm{g} \mathrm{ml}^{-1}\right)_{\mathrm{b}}=21.5 A_{646.8}-5.1 A_{663.2} \\
& \text { Carotenoids }_{(x+c)}\left(\mu \mathrm{g} \mathrm{ml}^{-1}\right)=\left(1000 A_{470}-1.82 \mathrm{Chl}_{\mathrm{a}}-85.02 \mathrm{Chl}_{\mathrm{b}}\right) / 198
\end{aligned}
$$

\subsection{Determination of carbohydrates}

\subsubsection{Total carbohydrate}

Preliminary hydrolysis to convert polysaccharides into monosaccharaides was performed by using of $2.5 \mathrm{~N} \mathrm{HCl}$. The total carbohydrate content was estimated by phenol-sulfuric acid method as (Dubois et al., 1956).

\subsubsection{Soluble and insoluble sugar}

Extraction of both sugars and starch was done according to (MoCREADY et al., 1950). Dried sugar free pellet hydrolysis to convert starch into monosaccharaides by using $52 \%(\mathrm{v} / \mathrm{v})$ perchloric acid.

Total soluble sugar and starch content was estimated by phenol-sulfuric acid method as (Dubois et al., 1956). Starch content calculated by multiplying by 0.91 . Reducing sugar was 
estimated according to (Nelson, 1944). Non-reducing sugar were determined by subtracting the content of reducing sugars from the amount of total soluble sugars (Shahidi et al., 1999).

\subsubsection{Estimation of minerals}

Plant tissue $(0.1 \mathrm{~g})$ finely ground oven dry digested by mixture of concentrated $\mathrm{H}_{2} \mathrm{SO}_{4}$ and $30 \% \mathrm{H}_{2} \mathrm{O}_{2}$ as the procedure described by (NJOGU, 2012).

Total nitrogen was spectrophotometric determined according to (Weatherburn, 1967) method. The absorbance measured at $650 \mathrm{~nm}$. Spectrophotometric determination of total Phosphorus content using 5\% molybdenum blue procedure with 5\% ascorbic acid (AA) as reducing agent according to (Jastrzębska, 2009). The absorbance was measured at $825 \mathrm{~nm}$.

Potassium were measured by flame emission photometry according to (Okalebo et al., 2002).

\subsubsection{Estimation of total soluble proteins}

Quantitative estimation of protein was executed by (Bradford, 1976) method. Absorbance was measurement at $595 \mathrm{~nm}$.

\subsection{Statistical analysis}

All the obtained data were subjected to one way statically analysis of variance (ANOVA) according to (Neter et al., 1996) using MSTAT-C program. Duncan's test was used for means separation.

\section{Results and discussion}

Figure 3.1 revealed that particles of Nano-CS-NPK fertilizer appeared in phloem tissue of potato leaves, especially in sieve tube. The diameter of nanoparticles presents inside sieve tubes showed a mean diameter varying $26.21 \pm 0.02 \mathrm{~nm}$ and more accumulation in leaves treated by Nano-CS-NPK $100 \%$. When nanoparticles are applied on leaf surfaces, they enter through the stomata openings the substomatal chamber or through the bases of trichomes and then are translocated to phloem system (Uzu et al., 2010). Du et al. (2011) also found that nanoparticles induce formation of new larger pores in plant cell wall to allow the entrance of large nanoparticles. In the cytoplasm, the nanoparticles may bind with different organelles in it and interfere with the metabolic processes (Abdel-Aziz et al., 2016). The observed results indicate that phloem potato tissue is the main and unique pathway for translocation of nanoparticles and confirm the penetration of plant leaves. Similar results were obtained by Wang $\boldsymbol{e t}$ al. (2013). For successful foliar uptake, in addition particle size, other various factors should also be considered 
such as working environment (light, water and gas), plant species and nanoparticle application methods (Abdel-Aziz et al., 2016).

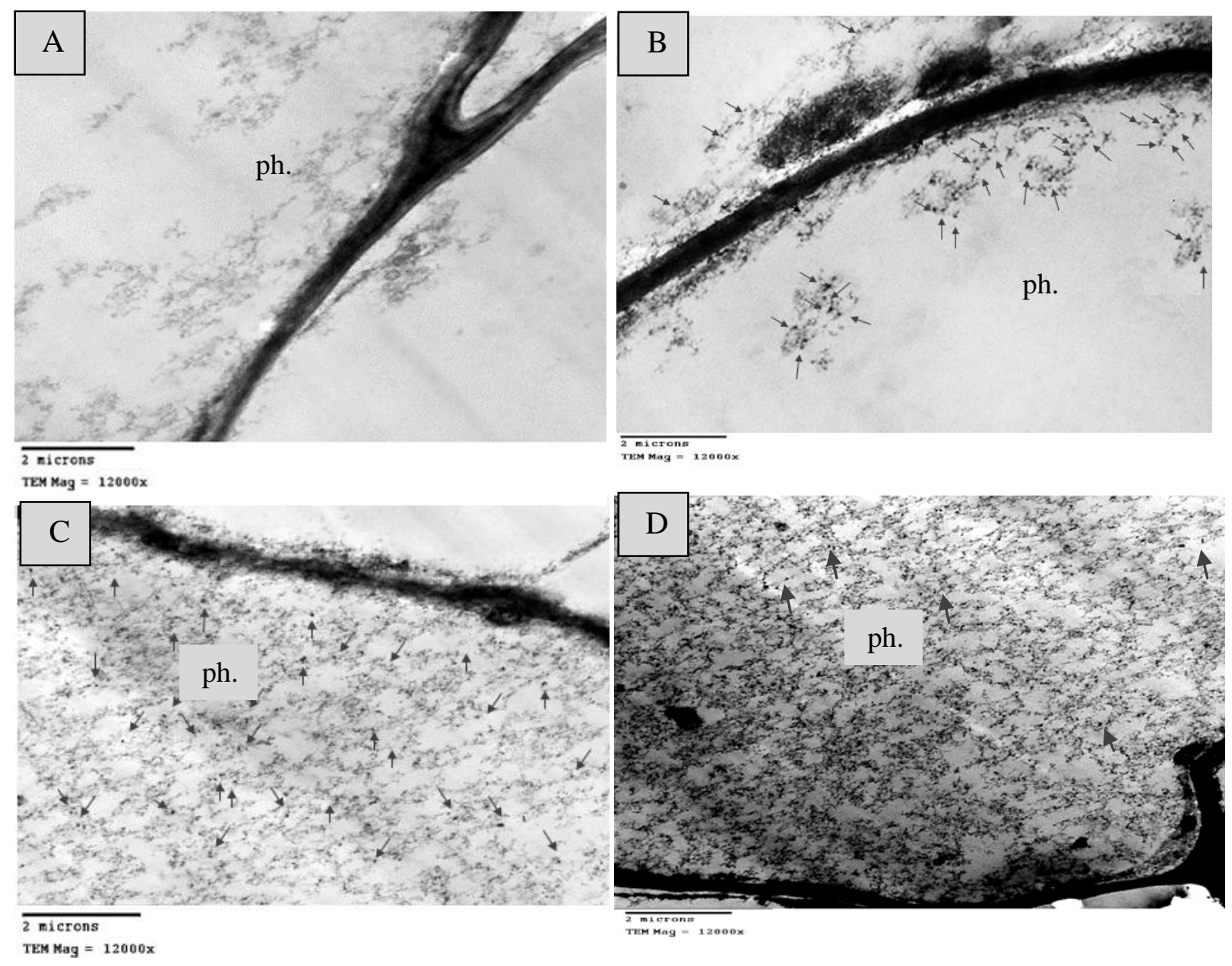

Figure 3.1 TEM micrograph of phloem tissue of potato leaves treated with Nano-CS-NPK fertilizer. (A) Control, (B) Nano-CS-NPK 10\%, (C) Nano-CS-NPK $50 \%$, (D) Nano-CS-NPK $100 \%$. Bar: $2 \mu \mathrm{l}$. Arrow indicates to nanoparticles 
Table 3.1 Vegetative growth parameters in potato ( 70 day after emergency) sprayed with normal and different concentrations of nanofertilizers (Nano CS-NPK 100, 50 and 10\%).

\begin{tabular}{cccccc}
\hline Treatments & $\begin{array}{c}\text { Length } \\
(\mathbf{c m})\end{array}$ & $\begin{array}{c}\text { FW } \\
(\mathbf{g}) / \text { plant }\end{array}$ & $\begin{array}{c}\text { DW } \\
(\mathbf{g}) / \text { plant }\end{array}$ & $\begin{array}{c}\text { Dry matter } \\
(\%)\end{array}$ & $\begin{array}{c}\text { Water content } \\
(\%)\end{array}$ \\
\hline Control & $83.11 \pm 0.03 \mathrm{c}$ & $85.06 \pm 0.49 \mathrm{~d}$ & $11.30 \pm 0.91 \mathrm{e}$ & $13.3 \pm 0.63 \mathrm{c}$ & $86.67 \pm 2.63 \mathrm{c}$ \\
Bulk NPK & $97.51 \pm 0.14 \mathrm{~b}$ & $114.5 \pm 0.19 \mathrm{c}$ & $21.75 \pm 0.78 \mathrm{~d}$ & $19.04 \pm 0.80 \mathrm{~b}$ & $80.96 \pm 0.70 \mathrm{c}$ \\
\hline Nano CS-NPK 10\% & $112.0 \pm 0.25 \mathrm{a}$ & $135.7 \pm 0.07 \mathrm{a}$ & $32.39 \pm 0.92 \mathrm{a}$ & $23.87 \pm 0.51 \mathrm{a}$ & $76.13 \pm 0.51 \mathrm{a}$ \\
Nano CS-NPK 50\% & $100.1 \pm 0.75 \mathrm{~b}$ & $120.0 \pm 0.50 \mathrm{~b}$ & $26.13 \pm 0.85 \mathrm{~b}$ & $21.77 \pm 0.68 \mathrm{a}$ & $78.23 \pm 0.68 \mathrm{~b}$ \\
Nano CS-NPK & $96.41 \pm 0.01 \mathrm{~b}$ & $103.4 \pm 0.58 \mathrm{~b}$ & $19.12 \pm 0.81 \mathrm{c}$ & $18.54 \pm 0.79 \mathrm{~b}$ & $81.46 \pm 0.79 \mathrm{~b}$ \\
$\begin{array}{c}\text { F-valu } \\
\text { F-value }\end{array}$ & $66.379 * *$ & $69.177 * * *$ & $142.867 * * *$ & $25.538 * * *$ & $25.538^{* * *}$ \\
\hline
\end{tabular}

Means with the same litters not significant. $* *: \mathrm{P}<0.01, * * *<0.001$.

Table 3.2 Root growth parameters in potato ( 70 day after emergency) sprayed with normal and different concentrations of nanofertilizers (Nano CS-NPK 100, 50 and 10\%).

\begin{tabular}{cccccc}
\hline Treatments & Length & FW & DW & Dry matter & Water content \\
\hline Control & $12.95 \pm 0.4 \mathrm{c}$ & $4.88 \pm 0.01 \mathrm{~d}$ & $0.65 \pm 0.30 \mathrm{~d}$ & $13.70 \pm 0.11 \mathrm{~b}$ & $86.30 \pm 0.41 \mathrm{~b}$ \\
Bulk NPK & $20.21 \pm 0.61 \mathrm{~d}$ & $10.4 \pm 0.50 \mathrm{c}$ & $2.46 \pm 0.06 \mathrm{c}$ & $23.47 \pm 0.81 \mathrm{a}$ & $76.53 \pm 0.81 \mathrm{~b}$ \\
\hline Nano CS-NPK & $25.73 \pm 0.85 \mathrm{a}$ & $14.2 \pm 0.58 \mathrm{a}$ & $3.47 \pm 0.13 \mathrm{a}$ & $24.77 \pm 0.68 \mathrm{a}$ & $75.23 \pm 0.68 \mathrm{a}$ \\
Nano CS-NPK & $24.01 \pm 0.46 \mathrm{~b}$ & $13.4 \pm 0.70 \mathrm{a}$ & $3.26 \pm 0.18 \mathrm{a}$ & $25.01 \pm 0.58 \mathrm{a}$ & $75.00 \pm 0.06 \mathrm{~b}$ \\
\hline Nano CS-NPK & $18.71 \pm 0.36 \mathrm{c}$ & $8.81 \pm 0.60 \mathrm{~b}$ & $2.00 \pm 0.16 \mathrm{~d}$ & $22.67 \pm 0.58 \mathrm{a}$ & $77.33 \pm 0.58 \mathrm{~b}$ \\
\hline F-value & $226.143^{* *}$ & $74.939^{* *}$ & $112.157^{* *}$ & $17.976^{* *}$ & $17.976^{* *}$ \\
\hline
\end{tabular}

Means with the same litters not significant. $* *: \mathrm{P}<0.01, * * *<0.001$.

The results of growth parameters are presented in Table 3.1; 3.2 showed that application of potato plants with either normal NPK fertilizer or different concentrations of nanofertilizers led to significant increase in all growth variables were measured as length, fresh weight, dry weight and dry matter except water content for shoot (Table 3.1) and root (Table 3.2), at fully vegetative growth stage. The values of measuring growth variables were higher in nanofertilizers-treated plants than in normal fertilizer-treated plants except Nano CS-NPK100\%. The following sequence of treatments (Nano $10>$ Nano $50>$ normal > Nano $100>$ C) was displayed with potato plants grown on sandy loam soil for all the vegetative and yield variables throughout the entire period of the experiment. Fertilizer is one of major factors that effect on growth and yield of various crops and vegetables. They are supplied by three main nutrients: nitrogen, phosphorus, potassium and macro or/and micronutrient.

However, the applied normal fertilizers is lost to the environment and cannot be absorbed by plants, causing not only substantial economic and resource losses but also very serious environmental pollution (Rai et al., 2015). Nanofertilizers harmonized the release of fertilizer N, $\mathrm{P}$ and $\mathrm{K}$ with their uptake by crops, so preventing undesirable nutrient losses to soil, water and air via direct entry by crops, and avoiding the interaction of nutrients with soil, microorganisms, water and air (Adisa et al., 2019). Mahmoodzadeh et al. (2013) and Abdel-Aziz et al. (2016) 
reported that direct exposure of wheat plants to specific type of nanoparticles caused significant increase in all growth parameters determined at optimum concentrations of nanosolution.

Table 3.3 Yield parameters in potato (90 day after emergency) sprayed with normal and different concentrations of nanofertilizers (Nano CS-NPK 100, 50 and 10\%).

\begin{tabular}{lccccc}
\multicolumn{1}{c}{ Treatments } & $\begin{array}{c}\text { No. of tubers } \\
\text { /plant }\end{array}$ & $\begin{array}{c}\text { Tuber } \\
\text { yield/plant } \\
(\mathbf{g})\end{array}$ & $\begin{array}{c}\text { Average tuber } \\
\text { weight } \\
(\mathbf{g})\end{array}$ & $\begin{array}{c}\text { DW of } \\
\text { tubes/plant } \\
(\mathbf{g})\end{array}$ & $\begin{array}{c}\text { Tuber dry } \\
\text { mater/plant } \\
(\%)\end{array}$ \\
\hline Control & $4.33 \pm 0.58 \mathrm{~d}$ & $392.0 \pm 0.40 \mathrm{~d}$ & $74.17 \pm 0.85 \mathrm{~d}$ & $74.36 \pm 0.33 \mathrm{e}$ & $18.97 \pm 0.25 \mathrm{c}$ \\
Bulk NPK & $7.33 \pm 0.58 \mathrm{c}$ & $583.3 \pm 0.51 \mathrm{c}$ & $91.07 \pm 0.02 \mathrm{c}$ & $132.8 \pm 0.04 \mathrm{~d}$ & $22.77 \pm 0.21 \mathrm{~d}$ \\
$\begin{array}{l}\text { Nano CS-NPK } \\
\mathbf{1 0 \%}\end{array}$ & $8.67 \pm 0.58 \mathrm{a}$ & $684.7 \pm 0.60 \mathrm{a}$ & $117.2 \pm 0.01 \mathrm{a}$ & $171.2 \pm 0.22 \mathrm{a}$ & $25.00 \pm 0.30 \mathrm{a}$ \\
$\begin{array}{l}\text { Nano CS-NPK } \\
\mathbf{5 0 \%}\end{array}$ & $7.67 \pm 0.58 \mathrm{ab}$ & $627.3 \pm 0.11 \mathrm{~b}$ & $99.73 \pm 0.62 \mathrm{~b}$ & $149.5 \pm 0.55 \mathrm{~b}$ & $23.84 \pm 0.29 \mathrm{~d}$ \\
$\begin{array}{l}\text { Nano CS-NPK } \\
\mathbf{1 0 0 \%}\end{array}$ & $6.43 \pm 0.57 \mathrm{bc}$ & $552.1 \pm 0.08 \mathrm{c}$ & $88.17 \pm 0.45 \mathrm{c}$ & $128.4 \pm 0.06 \mathrm{c}$ & $21.37 \pm 0.21 \mathrm{c}$ \\
\hline F value & $24.3 * * *$ & $108.414 * * *$ & $39.086^{* * *}$ & $156.011 * *$ & $167.403^{* *}$ \\
\hline
\end{tabular}

Means with the same litters not significant. $* *: \mathrm{P}<0.01, * * *<0.001$.

The data in Table 3.3 showed that the change in potato yield treated with normal and different concentration of nanofertilizers (Nano CS-NPK). The results indicated that treatment with nanofertilizers significantly increased in the number of tubers /plant, tuber yield /plant (g) average tuber weight (g), dry weight of tubers /plant (g) and tuber dry mater/plant (\%) for tuber yield at harvest stage as compared with control. Highest values of $\mathrm{N}, \mathrm{P}$ and $\mathrm{K}$ in shoots and tubers of potato plants were obtained by using Nano CS-NPK10\% as compared with other treatments. The concentration of $10 \%$ recorded the highest potato yield parameter. The obtained results in this investigation are in good agreement with those obtained by Hasaneen and Abdelaziz (2016b) who reported that the increased growth parameters of French bean plants as influenced by foliar application of either nanocomposite NPK nanoparticles or nano-engineered CNTs-NPK. The NPK effect on vegetative growth and yield of potato has been documented by BĂRĂSCU et al (2015) and Mokrani et al. (2018b). Potato plant needs a high level of nitrogen fertilizer for a fast cycle, high growth rate and increased the number of tubers (Mokrani $\boldsymbol{e t}$ al., 2018b). Low $\mathrm{N}$ rates not only lower yield but also reduce tuber size due to reduced early defoliation and leaf area (Jin $\boldsymbol{e t}$ al., 2015). Nowadays, application of fertilizers containing NPK is vital for the development of crop production and plays important roles in food safety. The importance of these NPK fertilizers lies in their role to supply the necessary nutrients for plant growth (Mokrani et al., 2018). When a nanoengineered composite which consists of N, P, K, micronutrients, mannose and amino acids was applied to grain crops, it appeared to enhance the uptake and use of nutrients (Abdel-Aziz et al., 2016; Biosci et al., 2014; Mastronardi et al., 
2015). Mokrani et al. (2018a) showed also a lowest potato plant length, stem diameter and few numbers of potato tubers with low weight under excess NPK fertilization rates.

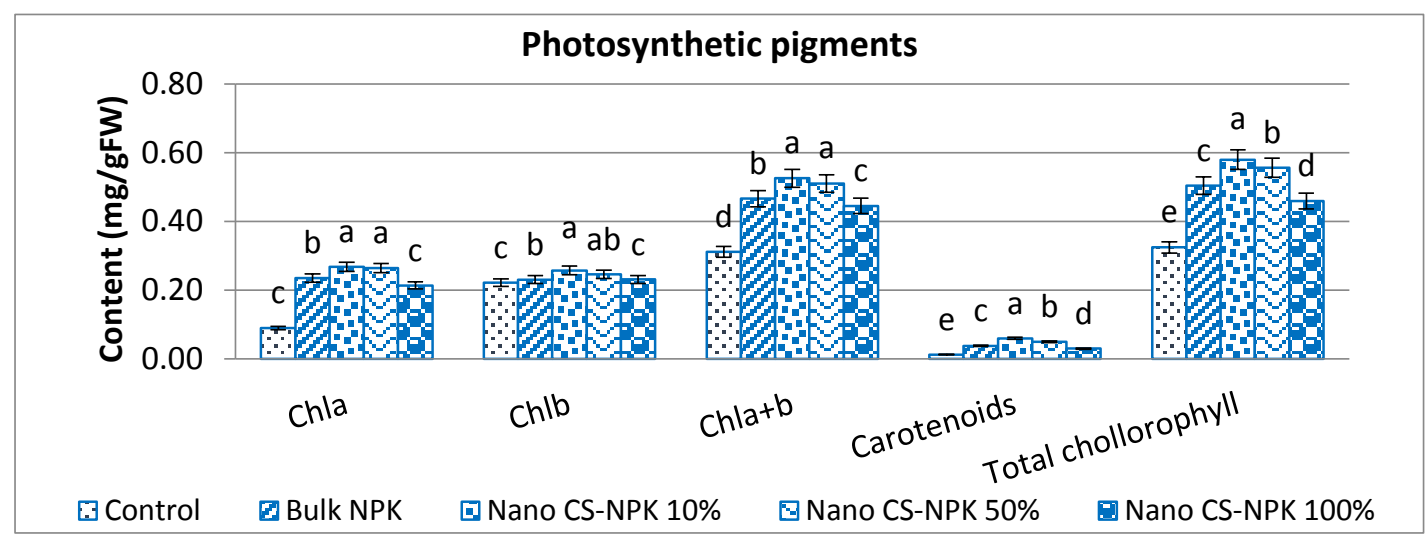

Figure 3.2 Photosynthetic pigments content $(\mathrm{mg} / \mathrm{g} \mathrm{FW})$ in potato leaves (70 day after emergency) sprayed with normal and different concentrations of nanofertilizers (Nano CS-NPK 100, 50 and 10\%). Vertical bars represent the standard division $( \pm \mathrm{SD})$. Different letters above the bars indicate significant difference using Duncan's multiple range tests at $\mathrm{P}<$ 0.05 , for samples.

Chlorophyll is the light harvesting pigment responsible for photosynthesis. Sufficient amount of chlorophyll means greater production of photosynthesis responsible for the growth and development. The obtained results in Figure 3.2 is the same of those obtained from the growth parameters and yield. The highest values of photosynthetic pigment were obtained by using Nano-CS-NPK 10\% fertilizer comparing to the other treatments. The increases in the photosynthetic pigments in shoots may be attributed to the important role of $(\mathrm{P})$ in the potential activity of photosynthesis. Ibrahim and Mohamed (2012b) found that photosynthetic pigments in potato leaves increased significantly by increasing NPK levels. Fageria et al. (2009) found that the favorable effect of NPK on photosynthetic pigments may be also due to N which is acting as structural compounds of the chloroplast. correspondingly, an enhancement chloroplast formation leads to an increase in chlorophyll. This study conducted by Mansouri and Omidi (2018) who found that treatment with $0.01 \% \mathrm{w} / \mathrm{v}$ Nano-CS and $0.5 \% \mathrm{w} / \mathrm{v}$ potassium nitrate enhance in the highest germination percentage, stem length, chlorophyll content and relative water content of Quinoa seedlings. It seems that NPK treatment significantly increased carotenoids in potato shoots. These results are in agreement with those obtained by Bojović $\boldsymbol{e t}$ al. (2005) and Tranavičienè et al. (2007) who reported that photosynthetic pigments in potato leaves increased by increasing NPK levels. Tranavičienè $\boldsymbol{e t}$ al. (2007) found that carotenoids in wheat leaves increased significantly by increasing $\mathrm{N}$ levels. 

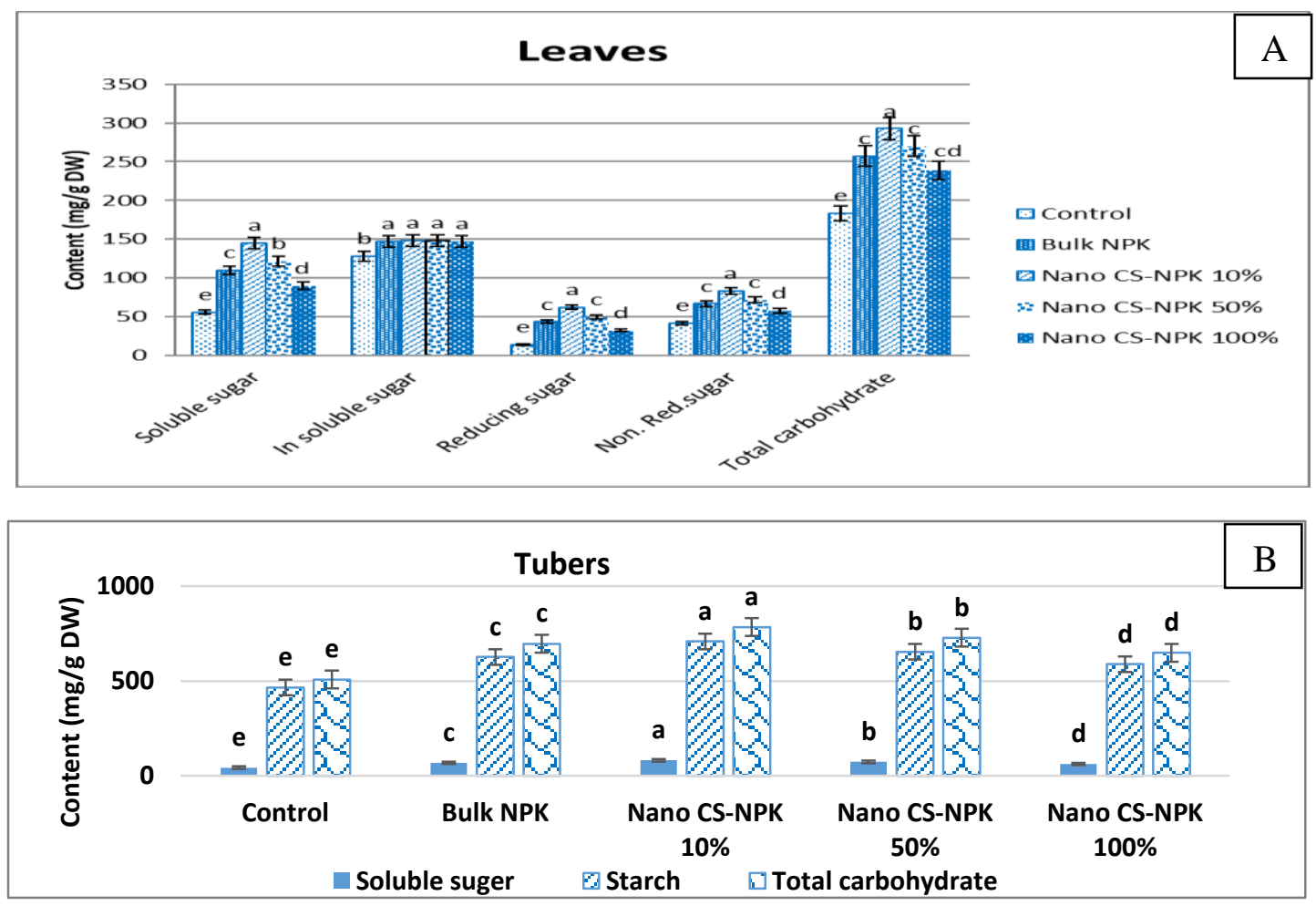

Figure 3.3 Carbohydrates content $(\mathrm{mg} / \mathrm{g} \mathrm{DW})$ in A; potato leaves (70 day after emergency), B; potato tubers (90 day after emergency sprayed with normal and different concentrations of nanofertilizers (Nano CS-NPK 100, 50 and 10\%). Vertical bars represent the standard division $( \pm \mathrm{SD})$. Different letters above the bars indicate significant difference using Duncan's multiple range tests at $\mathrm{P}<0.05$, for samples.

The obtained results, showed that treatments of potato plants with bulk material and chitosan NPK nanoparticles, induced significant increases in total carbohydrate, soluble and insoluble sugar, reduced and non-reduced sugar at fully vegetative growth stage (Figure 3.3a) and led to significant affected the tuber yield at harvest stage as total carbohydrate, soluble sugar and starch content (Figure 3.3b). Results clearly indicate an increase and build-up of stored starch during nanofertilizers and a dramatic depletion at Nano CS-NPK100\%. These results are in agreement with those obtained by Mokrani et al., (2018b) who reported that potato accumulated low amount of sucrose and starch under the excess regime in tubers, the levels of reducing sugars and starch in spunta leaves decreased by increasing NPK levels.

In this concern, Lindhauer and De Fekete (1990) reported that starch synthesis in potato tubers grown at varied $(\mathrm{k})$ nutrition activated some selected enzymes (sucrose synthase, UDP-D, glucose pyrophosphatase, starch phosphorylase, amylases). Comparing our results in (Figure 3.3), it is obvious that the positive correlations between the rates of $\mathrm{K}$ uptake and starch production indicate that the dynamic phase of $\mathrm{K}$ supply to the tubers has greater importance for 
starch synthesizing processes, than the influence of total $\mathrm{K}$ content. The obtained results agree with those obtained by (Mona et al. (2012) who mentioned that increasing NPK levels significantly increased the growth parameters, yield and its components as well as nutrient uptake of sugar beet and sweet sorghum plants. Ibrahim and Mohamed (2012b) and Mokrani et al. (2018b) proved that NPK application significantly increased reducing, non-reducing and total sugar as well as carbohydrates, starch, and protein contents in wheat grains and potato respectively.

Carbohydrate supply is essential for the high energy demanding process of nitrogen fixation. As well, a carbon skeleton for assimilation and transport of fixed nitrogen is provided by the same metabolic pathway intermediates (Chinnasamy and Bal, 2003). The potassium (K) applications is decreased reducing sugar (Zörb, et al., 2014), $\mathrm{K}$ application activates also a number of enzymes involved in photosynthesis, carbohydrate metabolism, proteins and assists in the translocation of carbohydrates from leaves to tubers, which increases the size of tubers but not their number (Hawkesford et al., 2012). Biomass and bulking rate of potato tubers are positively affected by synthesis and accumulation of starch. K plays a key role in stimulating the activity of the starch synthase enzyme, catalyzing the incorporation of simple glucose molecules into complex molecules of starch (Hawkesford et al., 2012).

Table 3.4. Nitrogen fractions content (mg/g DW) in potato leaves (70 day after emergency) sprayed with normal and different concentrations of nanofertilizers (Nano CS-NPK 100, 50 and 10\%).

\begin{tabular}{clcc}
\hline Treatments & \multicolumn{1}{c}{$\mathbf{N}$} & $\mathbf{P}$ & $\mathbf{K}$ \\
\hline Control & $16.76 \pm 0.07 \mathrm{~d}$ & $0.20 \pm 0.01 \mathrm{e}$ & $1.07 \pm 0.05 \mathrm{~d}$ \\
Bulk NPK & $21.64 \pm 0.12 \mathrm{~b}$ & $0.37 \pm 0.00 \mathrm{c}$ & $3.53 \pm 0.02 \mathrm{~b}$ \\
Nano CS-NPK 10\% & $23.44 \pm 0.12 \mathrm{a}$ & $0.44 \pm .00 \mathrm{a}$ & $3.77 \pm 0.01 \mathrm{a}$ \\
Nano CS-NPK 50\% & $22.11 \pm 0.04 \mathrm{~b}$ & $0.41 \pm 0.02 \mathrm{~b}$ & $3.67 \pm 0.01 \mathrm{~b}$ \\
Nano CS-NPK 100\% & $20.74 \pm 0.12 \mathrm{c}$ & $0.34 \pm 0.00 \mathrm{~d}$ & $3.20 \pm 0.09 \mathrm{c}$ \\
F value & $219.8 * * *$ & $1705.4 * * *$ & $626.2 * * *$ \\
\hline
\end{tabular}

Table 3.5. Nitrogen fractions content $(\mathrm{mg} / \mathrm{g} \mathrm{DW})$ in potato tubers ( 90 day after emergency) sprayed with normal and different concentrations of nanofertilizers (Nano CS-NPK 100, 50 and 10\%).

\begin{tabular}{cccc}
\hline Treatments & \multicolumn{1}{c}{$\mathbf{N}$} & $\mathbf{P}$ & $\mathbf{K}$ \\
\hline Control & $14.92 \pm 0.07 \mathrm{e}$ & $0.19 \pm 0.00 \mathrm{~d}$ & $0.77 \pm 0.10 \mathrm{~d}$ \\
Bulk NPK & $20.24 \pm 0.10 \mathrm{c}$ & $0.37 \pm 0.00 \mathrm{~b}$ & $3.49 \pm 0.02 \mathrm{~b}$ \\
Nano CS-NPK 10\% & $22.38 \pm 0.05 \mathrm{a}$ & $0.43 \pm 0.00 \mathrm{a}$ & $3.67 \pm 0.06 \mathrm{a}$ \\
Nano CS-NPK 50\% & $21.38 \pm .05 \mathrm{ba}$ & $0.38 \pm 0.03 \mathrm{~b}$ & $3.55 \pm 0.01 \mathrm{~b}$ \\
Nano CS-NPK 100\% & $19.38 \pm 0.03 \mathrm{~d}$ & $0.33 \pm 0.01 \mathrm{~d}$ & $2.41 \pm 0.01 \mathrm{c}$ \\
F value & $442.7 * * *$ & $154.2 * * *$ & $1037.3 * * *$ \\
\hline
\end{tabular}

Means with the same litters not significant. $* *$ : $\mathrm{P}<0.01, * * *<0.001$.

Data presented in Table 3.3; 3.4 revealed that macronutrients $(\mathrm{N}, \mathrm{P}$ and $\mathrm{K}$ ) in both leaves and tubers of potato plants were higher by applying different NPK fertilizers than that of control 
treatment. Highest values of $\mathrm{N}, \mathrm{P}$ and $\mathrm{K}$ in shoots and tubers of potato plants were obtained by using Nano-CS-NPK10\% as compared with other treatments. This finding is in agreement with results reported previously by (Abdel-Aziz et al., 2016; Biosci et al., 2014; Mastronardi et al., 2015) suggesting that when a nano-engineered composite which consists of $N, P, K$, micronutrients, mannose and amino acids was applied to grain crops, it appeared to enhance the uptake and use of nutrients. In this concern, Ibrahim and Mohamed (2012a) reported that foliar spray of micronutrients enhanced growth and increased the dry matter accumulation in potato and nutrients significantly increased the leaf content of the sprayed element. These effects may also due to the presence of macronutrients in the foliar fertilizers that may be mediated via the enzymatic systems responsible for biosynthetic apparatus, and thus rising sugars and nitrogen in intact plants. This means that foliar application of fertilizers induced increases in mineral status of plants.

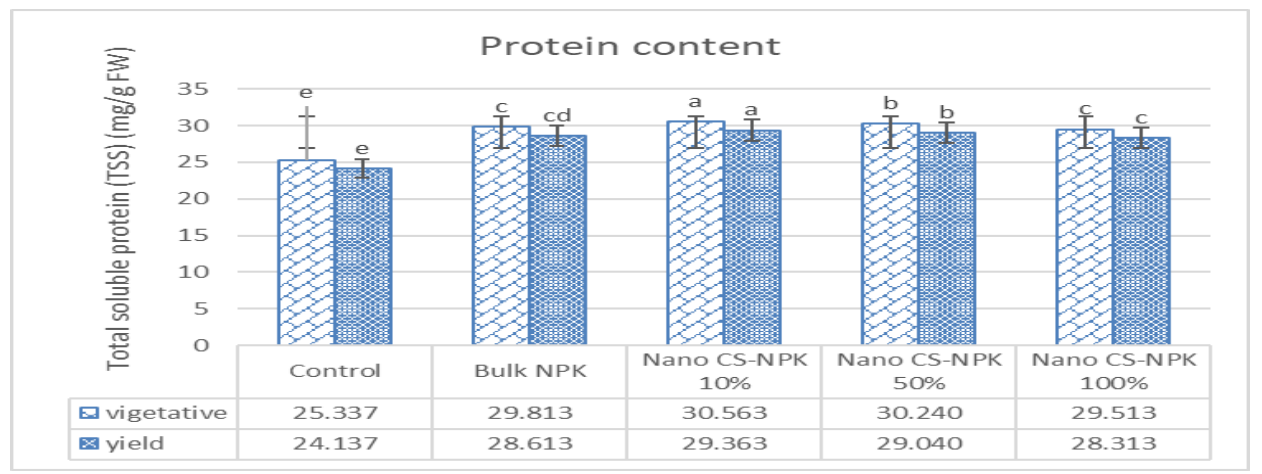

Figure 3.4 Total soluble protein (TSS) content (mg/g FW) in potato leaves (70 day after emergency) sprayed with normal and different concentrations of nanofertilizers (Nano CS-NPK 100, 50 and 10\%). Vertical bars represent the standard division $( \pm \mathrm{SD})$. Different letters above the bars indicate significant difference using Duncan's multiple range tests at $\mathrm{P}<0.05$, for samples.

Data presented in Figure 3.4 revealed that total soluble protein content in both leaves and tubers of potato plants were significantly higher by applying different NPK fertilizers than that of control treatment, which is in contrast to the conclusion of Abdel-Aziz et al. (2018) who reported that the effect of foliar application of Nano CS-NPK fertilizer on the chemical composition of wheat grains showed increasing levels of either normal or nanofertilizers induced significant decrease in protein content of the wheat grains, but how this works is not yet clear. It is supposed that nanofertilizers alter gene expression for protein synthesis during plant development similar to those observed in rice under drought conditions (Mushtaq et al., 2008). Some research suggested that the application of nanofertilizers decreased the protein content and increased the fat content of wheat plants (Abdel-Aziz et al., 2018). It seems that when foliar 
nutritionals were used, the photosynthetic activity was stimulated, leading to enhancement of chemical constituents as crude protein, starch, carbohydrate, L-ascorbic acid and T.S.S in shoots (Ibrahim and Mohamed, 2012b).

\section{Conclusion}

It can be concluded that foliar application of either normal or nanofertilizer (Nano CS-NPK) at different concentrations to potato plants, induced marked significant variable significantly increases in all growth variables of potato plant. Foliar application Nano-CS-NPK 10\% fertilizer shows the best nanofertilizers used and enhancing growth, productivity and chemical constituents of potato plants. Excessive use of fertilizer to enhance the crops productivity does not necessarily contribute to yield enhancement rather is mostly poses threat to human health and causes serious environmental problems. Our research would be beneficial for other studies involving the application of nanotechnology in the field of agriculture. Nevertheless, further field studies are needed to study the effect of different agrochemicals incorporation on growth and metabolism of different plants and to ensure the safety of the nanotreated plants for the use of animals and humans. Studies on the mechanism of uptake and formation of nanoparticles within plants have also need to more investigations. The importance of these NPK fertilizers lies in their role to supply the necessary nutrients for plant growth.

\section{References}

Abdel-Aziz, H., Hasaneen, M. N. and Omar, A. (2018) 'Effect of Foliar Application of Nano Chitosan NPK Fertilizer on the Chemical Composition of Wheat Grains', Egyptian Journal of Botany. National Information and Documentation Center (NIDOC), Academy of Scientific ..., 58(1), pp. 87-95.

Abdel-Aziz, H. M. M., Hasaneen, M. N. A. and Omer, A. M. (2016) 'Nano chitosan-NPK fertilizer enhances the growth and productivity of wheat plants grown in sandy soil', Spanish Journal of Agricultural Research, 14(1), pp. 1-9. doi: 10.5424/sjar/2016141-8205.

Adisa, I. O. et al. (2019) 'Recent advances in nano-enabled fertilizers and pesticides: A critical review of mechanisms of action', Environmental Science: Nano. Royal Society of Chemistry.

Arnon, D. I. (1949) 'Copper enzymes in isolated chloroplasts. Polyphenoloxidase in Beta vulgaris', Plant physiology. American Society of Plant Biologists, 24(1), p. 1.

BĂRĂSCU, N. et al. (2015) 'The effect of high NPK levels on potato yield size structure and tubers starch content.', Scientific Papers-Series A, Agronomy. University of Agronomic Sciences and Veterinary Medicine of Bucharest, 58, pp. 136-142. 
Bhushan, B. (2017) Springer handbook of nanotechnology. Springer.

Biosci, I. J., Farnia, A. and Ghorbani, A. (2014) 'Effect of K nano-fertilizer and N bio-fertilizer on yield and yield components of red bean ( Phaseolus vulgaris L .)', 6655, pp. 296-303.

Bojović, B. M., Stojanović, J. and Marković, A. (2005) 'Effects of fertilization on chloroplasts pigments content, leaf surface and dry matter weight in some wheat cultivars', Acta Agriculturae Serbica, 10(20), pp. 29-37.

Bradford, M. M. (1976) 'A rapid and sensitive method for the quantitation of microgram quantities of protein utilizing the principle of protein-dye binding', Analytical biochemistry. Elsevier, 72(1-2), pp. 248-254.

Chemistry, F. (2017) 'Cu-Chitosan Nanoparticle Mediated Sustainable Approach To Enhance Seedling Growth in Maize by Mobilizing Reserved...', (July 2016). doi: 10.1021/acs.jafc.6b02239.

Chinnasamy, G. and Bal, A. K. (2003) 'Seasonal changes in carbohydrates of perennial root nodules of beach pea', Journal of Plant Physiology, 160(10), pp. 1185-1192. doi: 10.1078/0176-1617-01090.

Corradini, E., De Moura, M. R. and Mattoso, L. H. C. (2010) 'A preliminary study of the incorparation of NPK fertilizer into chitosan nanoparticles', Express Polymer Letters. BUDAPEST UNIV TECHNOL \& ECON, 4(8), pp. 509-515.

De Moura, M. R., Aouada, F. A. and Mattoso, L. H. C. (2008) 'Preparation of chitosan nanoparticles using methacrylic acid', Journal of Colloid and Interface Science. Elsevier, 321(2), pp. 477-483.

$\mathrm{Du}$, W. et al. (2011) 'TiO 2 and $\mathrm{ZnO}$ nanoparticles negatively affect wheat growth and soil enzyme activities in agricultural soil', Journal of Environmental Monitoring. Royal Society of Chemistry, 13(4), pp. 822-828.

Dubois, M. et al. (1956) 'Colorimetric method for determination of sugars and related substances’, Analytical chemistry. ACS Publications, 28(3), pp. 350-356.

Fageria, N. K. et al. (2009) 'Foliar fertilization of crop plants', Journal of plant nutrition. Taylor \& Francis, 32(6), pp. 1044-1064.

FAO, I. (2016) 'WFP (2015), The State of Food Insecurity in the World 2015. Meeting the 2015 international hunger targets: taking stock of uneven progress', Food and Agriculture Organization Publications, Rome.

Hasaneen, M. N. A. and Abdel-aziz, H. M. M. (2016a) 'Effect of foliar application of engineered nanomaterials: carbon nanotubes NPK and chitosan nanoparticles NPK fertilizer on the growth of French bean plant', Biochemistry and Biotechnology Research, 4(4), pp. 68-76. 
Hasaneen, M. N. A. and Abdel-aziz, H. M. M. (2016b) 'Effect of foliar application of engineered nanomaterials : carbon nanotubes NPK and chitosan nanoparticles NPK fertilizer on the growth of French bean plant', Biochemistry and Biotechnology Research, pp. 68-76.

Hawkesford, M. et al. (2012) 'Functions of macronutrients', in Marschner's mineral nutrition of higher plants. Elsevier, pp. 135-189.

Ibrahim, E. E. and Mohamed, F. (2012a) 'Combined effect of NPK levels and foliar nutritional compounds on growth and yield parameters of potato plants ( Solanum tuberosum L .)', 6(24), pp. 5100-5109. doi: 10.5897/AJMR12.085.

Ibrahim, E. E. and Mohamed, F. (2012b) 'Combined effect of NPK levels and foliar nutritional compounds on growth and yield parameters of potato plants (Solanum tuberosum L.)', African Journal of Microbiology Research. Academic Journals, 6(24), pp. 5100-5109.

Jastrzębska, A. (2009) 'Modifications of spectrophotometric methods for total phosphorus determination in meat samples', Chemical Papers. Versita, 63(1), pp. 47-54.

Jin, V. L. et al. (2015) 'Twelve years of stover removal increases soil erosion potential without impacting yield', Soil Science Society of America Journal. The Soil Science Society of America, Inc., 79(4), pp. 1169-1178.

Juniper, B. E., Gilchrist, A. J. and Williams, P. R. (1970) 'Techniques for plant electron microscopy', Blackwell: Oxford \& Edinburgh, 108, pp. 1189-1190.

Lichtenthaler, H. K. and Buschmann, C. (2001) 'Chlorophylls and carotenoids: Measurement and characterization by UV- VIS spectroscopy', Current protocols in food analytical chemistry. Wiley Online Library.

Lindhauer, M. G. and De Fekete, M. A. R. (1990) 'Starch synthesis in potato (Solanum tuberosum) tubers: Activity of selected enzymes in dependence of potassium content in storage tissue', Plant and Soil. Springer, 124(2), pp. 291-295.

Mahmoodzadeh, H., Aghili, R. and Nabavi, M. (2013) 'Physiological effects of TiO2 nanoparticles on wheat (Triticum aestivum).', Technical Journal of Engineering and Applied Sciences. Science Explorer Publications, 3(14), pp. 1365-1370.

Malerba, M. and Cerana, R. (2016) 'Chitosan effects on plant systems', International journal of molecular sciences. Multidisciplinary Digital Publishing Institute, 17(7), p. 996.

Mansouri, A. and Omidi, H. (2018) 'Effect of Chitosan Nano Particle and Potassium Nitrate on Germination and Some Morpho-physiological Characteristics of Seedlings of Quinoa (Chenopodium quinoa)', Iranian Journal of Seed Research, 5(1). doi: 10.29252/yujs.5.1.147.

MoCREADY, R. M. et al. (1950) 'Determination of starch and amylose in vegetables. Application to peas.', Analytical Chemistry, 22, pp. 1156-1158.

Mokrani, K., Hamdi, K. and Tarchoun, N. (2018a) 'Communications in Soil Science and Plant Analysis Potato ( Solanum Tuberosum L .) Response to Nitrogen, Phosphorus and Potassium Fertilization Rates Potato ( Solanum Tuberosum L .) Response to Nitrogen , 
Phosphorus', Communications in Soil Science and Plant Analysis. Taylor \& Francis, 49(11), pp. 1314-1330. doi: 10.1080/00103624.2018.1457159.

Mokrani, K., Hamdi, K. and Tarchoun, N. (2018b) 'Potato (Solanum Tuberosum L.) Response to Nitrogen, Phosphorus and Potassium Fertilization Rates', Communications in Soil Science and Plant Analysis. Taylor \& Francis, 49(11), pp. 1314-1330.

Mona, E. E., Ibrahim, S. A. and Manal, F. M. (2012) 'Combined effect of NPK levels and foliar nutritional compounds on growth and yield parameters of potato plants (Solanum tuberosum L.)', African Journal of Microbiology Research. Academic Journals, 6(24), pp. 5100-5109.

Mushtaq, R., Katiyar, S. and Bennett, J. (2008) 'Proteomic analysis of drought stress-responsive proteins in rice endosperm affecting grain quality', Journal of Crop Science and Biotechnology. Citeseer, 11(4), pp. 227-232.

Nelson, N. (1944) 'A photometric adaptation of the Somogyi method for the determination of glucose', J. biol. Chem. Baltimore, 153(2), pp. 375-380.

Neter, J. et al. (1996) Applied linear statistical models. Irwin Chicago.

NJOGU, M. J. (2012) 'Mineral Levels of Some Plants and Their Leaf Extracts and Their Effects on Soil pH and Growth Rate of Selected Non-leunious Plants'. KENYATTA UNIVERSITY.

Okalebo, J. R., Gathua, K. W. and Woomer, P. L. (2002) 'Laboratory methods of soil and plant analysis: a working manual second edition', TSBFCIAT and SACRED Africa. Nairobi, Kenya.

Page, A. L., Miller, R. H. and Keeney, D. R. (1982) 'Methods of soil analysis. Part 2. Chemical and microbiological properties. Agronomy, No. 9', Soil Science Society of America, Madison, WI, p. 1159.

Rai, M. et al. (2015) 'Nanotechnologies in food and agriculture', Nanotechnologies in Food and Agriculture, (January), pp. 1-347. doi: 10.1007/978-3-319-14024-7.

Shahidi, F. et al. (1999) 'Chemical composition of beach pea (Lathyrus maritimus L.) plant parts', Food chemistry. Elsevier, 64(1), pp. 39-44.

Silver, B. (2013) 'Potatoes', Journal of Agricultural \& Food Information. Taylor \& Francis, 14(2), pp. 91-97.

Tranavičienè, T. et al. (2007) 'Effects of nitrogen fertilizers on wheat photosynthetic pigment and carbohydrate contents.', Biologija, (4).

Uzu, G. et al. (2010) 'Foliar lead uptake by lettuce exposed to atmospheric fallouts', Environmental Science \& Technology. ACS Publications, 44(3), pp. 1036-1042.

Wang, W.-N., Tarafdar, J. C. and Biswas, P. (2013) 'Nanoparticle synthesis and delivery by an aerosol route for watermelon plant foliar uptake', Journal of nanoparticle research. Springer, 15(1), p. 1417.

Weatherburn, M. W. (1967) 'Phenol-hypochlorite reaction for determination of ammonia', 
Analytical chemistry. ACS Publications, 39(8), pp. 971-974.

Williams, D. B. and Carter, C. B. (1996) 'The transmission electron microscope', in Transmission electron microscopy. Springer, pp. 3-17.

Zaheer, K. and Akhtar, M. H. (2016) 'Potato production, usage, and nutrition-a review', Critical reviews in food science and nutrition. Taylor \& Francis, 56(5), pp. 711-721.

Zörb, C., Senbayram, M. and Peiter, E. (2014) 'Potassium in agriculture-status and perspectives', Journal of plant physiology. Elsevier, 171(9), pp. 656-669. 


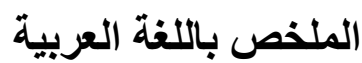

\section{تخليق النانوكيتوزان وتطبيقاته كسماد ومضاد للفطريات على البطاطس \\ مروة طلعت الثامي '، سامية محب الخلال '، شريف موسي الحسيني' و خالا يحى فروح'}

' قسم النبات، كلية البنات للأداب و العلوم و التربية، جامعة عين شمس، القاهرة، مصر.

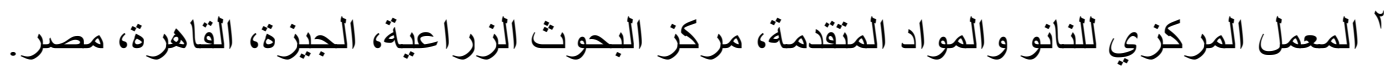

الأسدة النانوية من التقنيات المطورة لتحكم أكبر في تحرر الكيماويات الزر اعية لتحقيق أفضل تحسن

في المحاصيل النباتية مع تقليل التأثيرات السلبية على البيئية. تم دراسة تطبيق الإستخدام الورقي لجسيمات

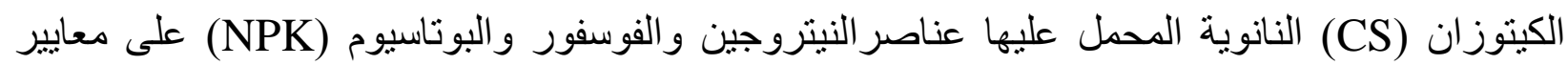

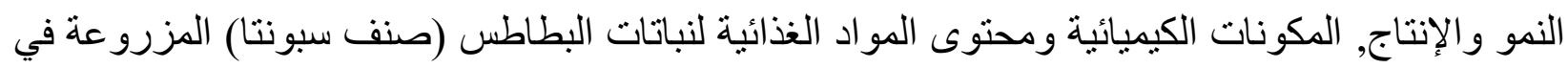

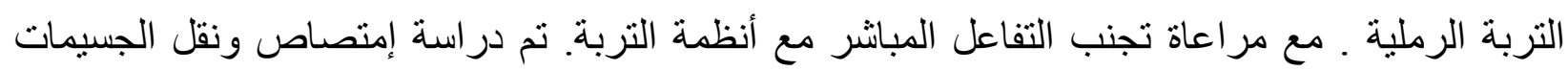
النانوية داخل نباتات البطاطس عن طريق المجهر الإلكتروني ـ أظهرت النتائج أن الجسيمات النانوية

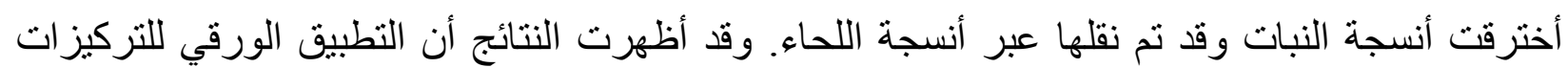

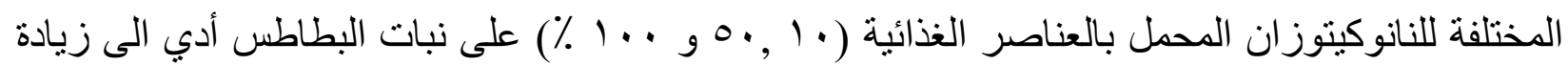

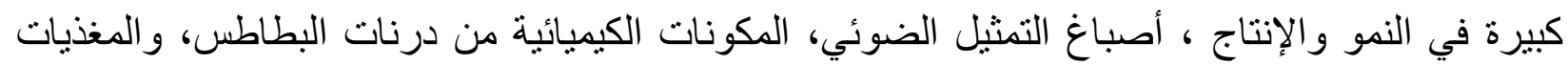

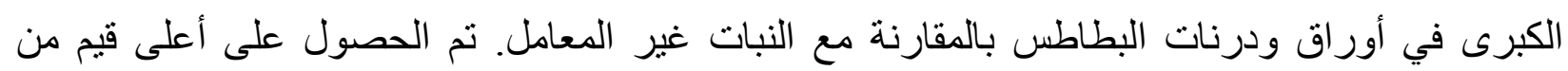

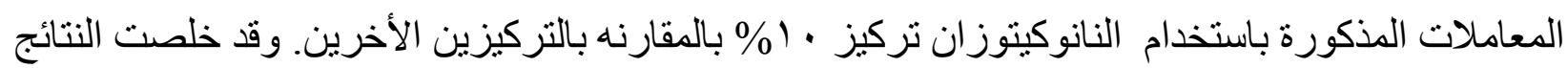

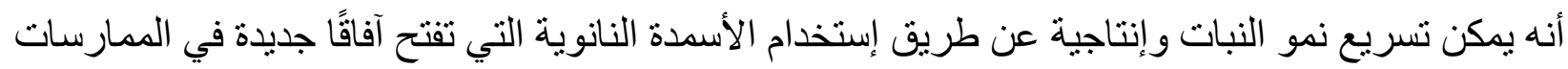

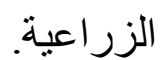

